\title{
Nelikümmend lindu eesti rahvausundis II
}

\section{$\underline{\text { Mall Hiiemäe }}$}

kajakas Ranna-aladel on kajakaid peetud hukkunud meremeeste vaimudeks. Kui kajakad meresõidu ajal visalt laeval püsivad ega taha lahkuda, on meremeeste arvates ootamas ees midagi halba:

Ka kajakad ei kuuluta hääd, kui nad suurel hulgal taklasis (taglases) istuvad ja igasuguse hirmutamise peale paigale jäävad või kohe tagasi tulevad. Vana merimees arvab neis merimeeste vaime nägevat, ja nimelt hukkunud merimeeste vaime, kes varitsevad peatsete seltsiliste järele. E 84613/4 (4) < Pärnu 1.

Üksikjuhtudel on kajakaparvede ilmumist sisemaale peetud samuti surma või laevahuku endeks. Maja kohal või noorpaarile laulatusesõdul vastu lendamine tähendab Saaremaa uskumustes head õnne: Kui laulatama minnes kalakajakas vastu lendis, siis tähendas see noorepaarile õnne. Kui vares lendis, siis õnnetust (Karja).

Ilmaennetes on kajakad rannarahva seas üsna populaarsed. vt kaarti Kui kajakad on madalal, siis tuleb sadu ja tormi. Kui kajakas lendab haruldaselt kõrgelt, nii et vaevalt näha on, siis tuleb kauemaks ajaks ilusat ilma (Haljala). Kajakate rahutu lend ning ilmumine sisemaale tähendab valdavalt tormi, vihma, üldse ilmamuutust. Tagasilend merele on tormi vaibumise enne.

\section{kakk - vt öökull}

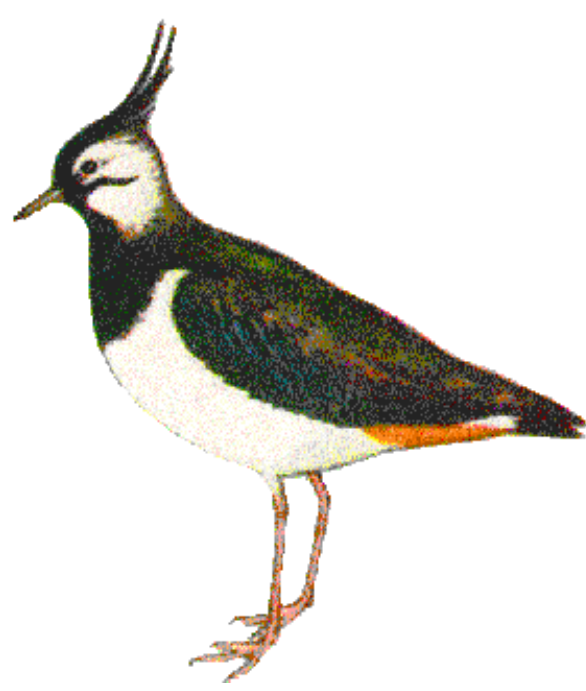

kiivitaja Vanellus vanellus. Kiivitajaid on arvatud olevat Eestisse ilmunud koos poolakatega (seega 16. sajandil). Poolakad olevat neid kasutanud sõdalaste eest peitu pugenute ülesotsimiseks.

Kiivelennud olid poolakatega seltsis tuln olnd. Kui nad inimest nägevad, siis nad karjuvad nende järele. Ju nad poola lennud olid. Kui paergu karjamaal käid, siis karjub su peale. Siis on kohe teada, et inimene käimas on. ERA II 62,146 (13) < Lääne-Nigula khk, Taebla v, Liidiküla - R. Põldmäe (1933). 
Kujutlust on aidanud süveneda selle linnuliigi ründav käitumine pesitsusajal: Kiivitaja on sõdade ajal põgenejatele väga vihatav lind olnud (Äksi). Kiivitaja hü̈̈d inimest märgates olevat Siin üks! või Veel üks! Seosele sõdade, näljaaegade ning surmariigiga vihjavad nimetused, nagu katkukull, poola lind, vaimulind, vaimukukk, vainukana (vrd soome $\mathrm{k}$ vainaja - surnu).

Kiiv hüitakse vainukanaks. Teda olla ennemuiste vaenuajal inimeste ülesotsimiseks pruugitud, kui inimesed kuskile ennast ära olla peitnud. Kiiv karjub ühtelugu oma otsimise- ja leidmisesõnu: "Siin üks, siin üks!" E 43004/5 (7) < Pöide khk, Tormimäe k - J. Prooses (1902).

Linnu käitumist iseloomustatakse kui inimvaenulikkuse ja sallimatuse väljendust:

Kiivit ei salli inimest, lend pähä, ku nende raja sisse lääd. Ku tal poja om, sitt pähä, nagu nooli lask. Kiivit om valgetkirja kirivene, seäntse pehme einämä sehen, jõõ ümmer eläs. Kiiviti kisuvä silmä pääst vällä. Miä küll ei tohi minnä, miä pelgä neid linde. AES I < Karksi khk, Ainja - A. Univere (1936).

Kevadehaljuse ning tulevaste saakide ootust väljendavad vanasõnad kiivitaja saabumise kohta (kõrvutavalt veidi hiljem saabuva koovitajaga): kiivit toob kindatäie (sooja), koovit kotitäie; kiivit toob kimbu heina, koovit toob koorma heina; toob paljad kingud (lumemineku aeg); toob kiku leiba. Kui kiivitaja saabub enne koovitajat, tulevat hea vilja-aasta, aga kui koovitaja saabub enne kiivitajat, siis kasvavat suvel hea hein, arvati Viljandimaal. Ki ivitaja hüüdu on peetud ka vihmasaju endeks. Tema omapärase häälitsuse kohta leidub veel seletusmuistend Kihnust:

au snd

Kiivitaja ja lõokesed, $1.6 \mathrm{Mb}$.au

Üks räästas, kis tuha sies üles kasvan, lendäs ükskord vällä. Sai kiivitigä kokko. Kiivit küsis varsti: "Mis nied inimesed riäkvad omiti neist lindude laulamisest?"

Rästas kostis: "Ei ühtigi. Ööbik saab igas kohtas ki idetud ja lõokõ saab suurõ au sies pietud. Mõnikord nimetäkse mind kua."

Kiivit küsis varsti: "Kas minust räägitä ühtigi?"

"Ei sind nimetätägi!"

Kiivit lendäs üles taeva alla. Akkas ise ennast kiitma:

"Kiivikk, kiivikk!" ERA II 58, 691 (9) < Kihnu khk - T. Saar (1932).

kivitäks Oenanthe oenanthe. Kivitäksu munadele on omistatud nahka kahjustavat toimet (tulevad paised, kärnad). Kes tema muna pihku võtab, selle käed lähevad kärna. Muna sisuga kokku puutunud kohale tekib paise. Tähenduslik on ka selle linnu esmakordne nägemine või kuulmine kevadel:

Kui esimest korda nägi varedikku kevade kiviaja pääl

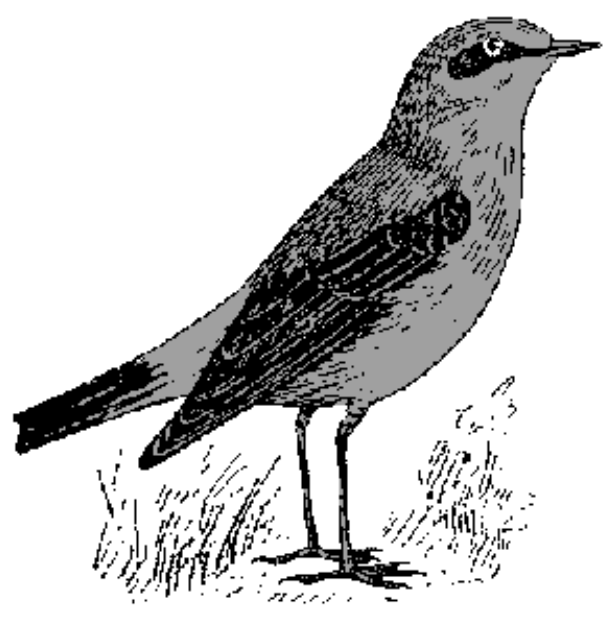


tiksumas, siis olid sui paised ümber. Kui varedikk aga lendis, siis pole midagi viga oln karta. Varediku muna koor, mis maas oli, selle pääle pole vein astuda mitte. See tegi jalatalla alla paiseid. Varediku pesale pole tohtin midagi äda teha mitte. Siis tulid paised ümber. Karja khk, Pärsamaa v, Pamma k - O. Grepp (1940).

au snd

Kivitäks, $600 \mathrm{~kb} . a u$

Häälitsemise järgi kevadel (maas või kivi otsas, üks või kaks korda järjest) on Lõuna-Eestis otsustatud veel lina- ja vil jasaagi õnnestumist.

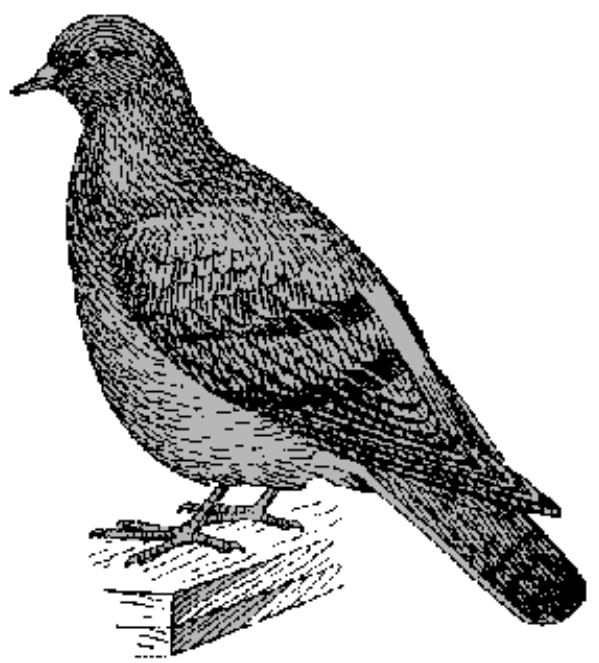

kodutuvi Columba livia. Mütoloogilised kujutelmad tuvide kohta seostuvad põhiosas kodutu viga. Need on laenulised ning suhteliselt hilised, levinud enamjaolt Lõuna-Eestis: tuvi on jumala peni; tuvi on patt tappa; tuvi on vaga lind, kelle liha ei tohi süüa; on hea, kui majas elutseb tuvi. Sporaadiliselt tuleb ette uskumust, et hoonesse, kus kodutuvid pesitsevad, pikne ei löö.

Tuvist kui õnnelinnust on teateid õpilasfolkloorist: kui tuvi lendab vastu akent, toob õnne, valge tuvi nägemine kuulutab onne, tuvi katusel tähendab, et päev on edukas. Tiirleva tuvi nägemine tähendab kirja saamist. Kui näeb tuvikest mitu korda sama maja ümber tiirlevat, siis saab kirja (Pärnu 1).

20. sajandi kultuuripildis on tuvid armastuse sümbol, eriti piltpostkaartidel. Kodutuvide nägemisel endid pesemas arvati peagi vihma tulevat. Nii metsas elutsevate tuviliikide kui kodutuvide äkilise ilmumise puhul maja juurde arvati järgnevat majaelaniku surma.

\section{kotkas - vt kull}

kull Nii kotka, hauka, pistriku kui *öökulli (kaku) kohta kehtib ühine nimetus kull. Leg endi järgi on Juudas või kurat loonud teiste kurjade olendite seas ka kulli. Muistendeis võib kull olla üks metshaldja või kuradi esine miskujusid. Näiteks ilmub kütile lõkketule äärde kull ja muutub inimeseks, kellest hõbekuuliga laskmisel jääb järgi vaid sinist suitsu. Üleloomulike olendite hulka kuulub ka teisi linde taga kihutav *nõiakull või lapikull. Runolauludes on kull (kotkas) noormehe sünonüüm.

Mitmete rahvauskumuste lähtealuseks on kulliliste murdjaloomus.Kokkupuute vältimiseks nendega tuli hoiduda kulli nime nimetamast: Kui kulli sööma-ajal nimetad, siis teeb see kanadele ja teistele väikstele lin dudele paha. Juhtub, et nendest

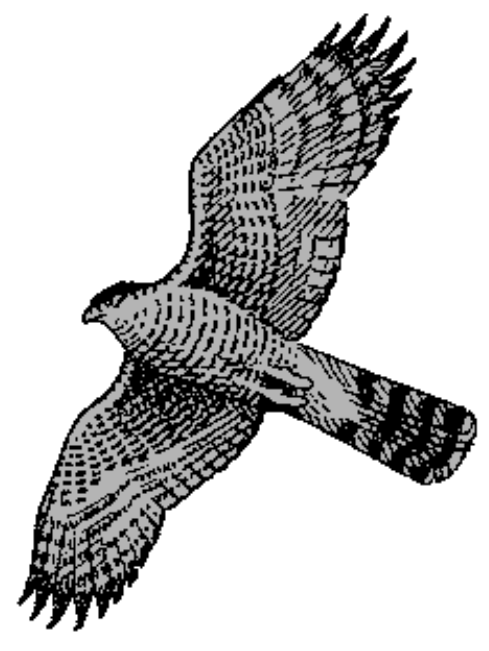


sööma-ajal jutt tuleb, siis tuleb küll jutusta, aga mitte nimeta. - Räägi meest, aga ära nimeta. EKS $4^{\circ} 5,359(5)<$ Karja khk). Ühe teate järgi on kullil teatavatel tingi mustel õigus oma saagile: Iga kulli järele peab alati tingimata üks väike lind lendama. Kui kull ei peaks kolmel päeval saaki leidma, siis peab ta selle väikese linnu ära sööma. Enne kolme päeva ei ole kullil õigust seda pisikest lindu puutuda. Sellepärast lendavadki kulli järele alati linnud. E 46099 (4) < Simuna khk V. Rosenstrauch (1907)

Arvati, et kui kulli püssist lasta ja ta jääb ellu, saab sellest pärast suur murdja. Kulliks muutuma ning pisikesi linde murdma pidi suvel pärast kukkumiseaja lõppu ka kägu . Kui sooviti tigedaid mesilasi, kes teiste mesilasperede mett rööviksid, tuli nad kevadel lasta läbi kulli kõri minna. Mahalastud kullilisi nagu *kakkegi on löödud laiali tiibadega loomalauda või hobusetalli ukse kohale või seinale. See pidi kaitsma painaja vastu. vt kaarti

Olen mõneski kohas Eestis käinud ja peaaegu igal pool näinud lautade, tallide uste kohal kulli ehk kotka naelutatud olevat. See kinninaelutatud kull ehk kotkas on selleks uksele pandud, et nõidust ega luupainet loomade kallale lauta ei pääseks. E X 35 (169) < M.J.Eisen.

Teadetes on märgitud, et niisugust tõrjeviisi kasutati mõisates. Eestlastest mõisatööliste vahendusel levis see ka taluperedesse. Võtteid kanakulli tõrjumiseks talu juurest: vana luud või viht aiateibasse panna; kiviga või rapekondiga järele visata; paljast tagu mikku näidata. Keelatud oli kulli nimetamine söögilauas (tuli öelda näiteks: Mets võttis kana!), õuel kõndimine kirves õlal. Loitsusõnad kulli tõrjumiseks on: Kull, kull, kanavaras, pesa põleb, pojad sees!, Kull, kull, kanavaras, üle aia utevaras, meie mamma niidivaras!. Mõnevõrra on uskumusi inimsaatuse ettearvamisega: kotka tiirlemine sõjamehe pea kohal kuulutab võitu, teekäija pea kohal hädaohtu, karjumine teatab sur masõnumi saamist või vallaslapse sündi.

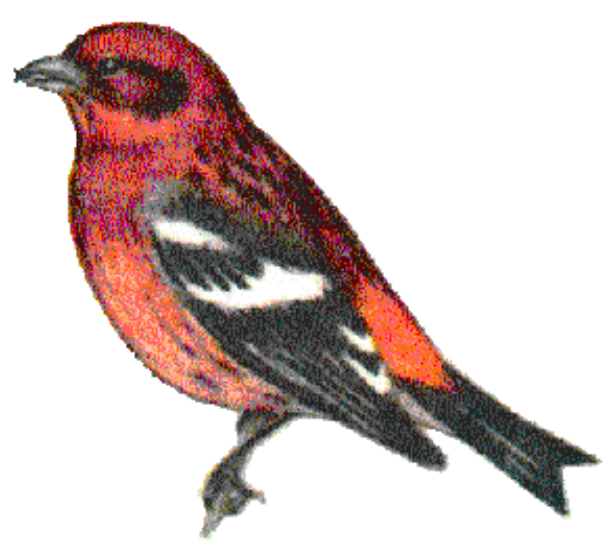

saanud linnud ristnoka nime; nende surnukehad ei pidavat mädanema. E 46896/7 (2) < Palamuse khk - H. Karu (1909).

kägu Cuculus canorus. Teiste linnuliikidega võrreldes on kägu eesti rahvausundis kõige popu laarsem lind. Kujutlus nokk paindunud ris tikujuliseks. Sellest käbilind Loxia. Põhja-Eestist on pärit mõned legendinoteeringud, et käbilind ehk ristnokk on oma nokapooled risti asetuvateks painutanud Jeesuse ristipuust naelu välja kiskudes ja tema laip ei mädane.

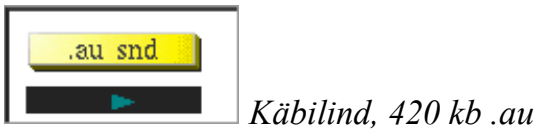

Parv ristnokalindusid olla Kolgata mäel kibuvitsa okkad Jeesuse pääst välja nokkinud. Tahtnud ka ristinaelu, millega Jeesus ristile löödud, välja kiskuda, pole jõudnud,

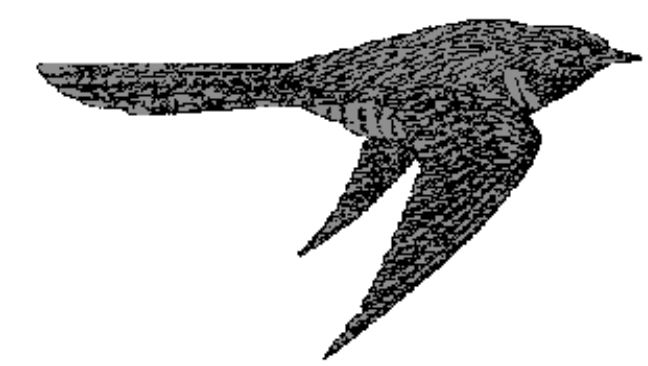


elu järjepidevusest inimhinge siirdumisega teise olend isse on esindatud rohkem kui sajas käo tekkeloo kirjapanekus nii runolaulu ku jul (laulutüüp "Vaeslaps käoks") kui muinasjutuna (AT 720).

Ka ühe vana jutu riismetest sain ma järgmise lou kätte, kudas kägu sündinud. Minu vanaema rääkis seda nõnda:

Ükskord kosis noorepäraline leskmees omale teise naise. See oli tige ega sallinud oma mehe tütart, kes esimesest naisest oli sündinud, sest et see virk ja viisakas ja väga ilus oli, kuna ta oma tütar inetu ja laisk oli. Nüüd hakkas ta kasutütart vihkama ja hellitas igapidi oma tütart. Kasutütar pidi kõik rasked tööd ära tegema ja selle tänupalgaks sai ta kurjaste tapelda ja mõnikord ka malka, aga ta oma tütar viitis vedeldes aega.

Kord saatis ema mõlemad tütred jõe äärest vett tooma. Oma tütrele andis ta ühe kindla karbi veenõuks ja ka sutütrele sõela. Mõlemad pidivad vett tooma, aga kasutütre veenõu ei pidanud vett. Ta oli nüüd õieti hädas ja tea dis: kui ta kauaks jääb ehk ilma veeta tagasi lähäb, siis saab ta jällegi vitsu. Aga üks veike lind õpetas teda, see laulis puu ot sas: "Heida liiva, heida liiva!" Vaenelaps mõistis seda ja viskas liiva sõela sisse. Liiv ummistas sõela ära ja sõel jäi veepidavaks. Vaenelaps viis küll vee tuppa, aga sai siiski kasuema käest kurjaste tapelda, et ta kauaks jäänud.

Sagedaste valas ka vaenelaps valupisaraid, aga ta täitis ka kõik, mis teda teha kästi. Sellega läks ta kõige meelest armsaks ja kõik kiitsivad teda, kuna nad teist laitsivad. Selle üle vihastas ema ja kat sus, kudas ta oma tütar üksi jääks ja kasutütre koguni eest ära saaks saata. Selle nõu saatis ta kavalalt korda.

Ta seadis ühe raske kirstu kaane üles ja saatis kasutütre selle kirstu seest ühte veikest asja ära tooma. Kirstu põhjast asja võttes kukkus õrnalt üles seatud kaan maha ja lõi vaese lapse surnuks. Tüki aja pärast läks ema vaatama, mis tütar nii kaua seal peaks tegema ja nägi, mis seal oli sündinud. Kui ta nägi, et kasutütar juba otsa saanud, siis ütles ta: "Näe, kus ta mait otsa saanud!" Pärast seda olnud kaua aega hääl kirstu sees kuulda: "Kukku, kukku."

Isa võttis oma lapse luud ja mähkis halli rätiku sisse ja viis nad metsa puukännu otsa. Sagedaste käis isa veel oma lapse luid vaatamas. Viimati märkas ta, et luud olivad kokku kasunud ja ka hall rätik luude külgi kinni kasunud, mis aegamööda sulgedeks muutis. Nüüd hakkas ka lind lendama ja laulis vahet pidamata: "Kukku, kukku!" Ta lendas ka kodu tagasi ja laulis ka maja katuseharja peal: "Kukku, kukku!" Siis kutsus ta lauldes ka oma õe välja: "Kukku, kukku, tule välja, mu õeke!" Kui õde välja tuli, siis kinkis ta õele kuldsõrmuse. Siis laulis ta edasi: "Kukku, kukku, tule välja, mu isake!" ja isale kinkis ta kuldvöö mälestuseks. Veel laulis ta: "Kukku, kukku, tule välja, mu emake!" Aga emale viskas ta raske kivi kaela. Peale selle lendas ta lauldes metsa, kus ka tänapäevani kukulinnu korter on. Et vana jutu järele kägu inimese sugust on, sellepärast ei lasta ka teda püssiga ja kui ta õue laulma tuleb, siis arvatakse, et ta kellegile inimesele õnnetust kuulutada. H III 5, 413/6 $<$ Vändra khk - J. Erm (1888).

Proosavormis tekstidele on omane kirjeldus, et vaeslapse luudele kasvasid liha ja suled peale, nii sündis kägu. Siia liitub uskumusi: sellepärast en nustabki käokukkumine maja juures surma, sellepärast polegi tal kodu, sellepärast ei tohi teda tappa jne. Põhjendus ei tarvitse olla esitatud muinasjutuna, vaid seda mainitakse napisõnalise mööndusena: kägu on saanud vaeslapse sõrmeluust, inimese (vaeslapse) südamest, hallist pearätist. Muinasjutule liituv või omaette esitatav regilaul kujutab endast tekkeloo ümberjutustust, nüüd juba käo enda lauluna, kusjuures iga värsi lõpul kordub tema häälitsust imiteeriv "kukku". 
Kissi sinu ära tappis, kukku, kukku? Ema minu ära tappis, kukku, kukku. Kissi sinu maha mattis, kukku, kukku? Isa minu maha mattis, kukku, kukku. Kissi sinu vere jõi, kukku, kukku? Veli minu vere jõi, kukku, kukku. Kissi sinu luud korjas, kukku, kukku? Sõsar minu luud korjas, kukku, kukku, sidus siidi rätti sisse, kukku, kukku, vei metsa kannu otsa, kukku, kukku, sealt mina käuks sain, kukku, kukku.
Läksin koju kukkumaie, kukku, kukku, kuuse otsa kukkumaie, kukku, kukku. Tule,ema, tunne tütart, kukku, kukku. Tuli ema, ei tunnud tütart, kukku, kukku.

Tule, isa, tunne tütart, kukku, kukku. Tuli isa, tundis tütart, kukku, kukku. Tule, vend, tunne sõsart, kukku, kukku. Tuli vend, tundis sõsart, kukku, kukku. Tule, sõsar, tunne sõsart, kukku, kukku.

Tuli sõsar, tundis sõsart, kukku, kukku
Isale said ilusad hobused, kukku, kukku, vennale said veduhärjad, kukku, kukku, sõsaralle said siidisukkad, kukku, kukku,

emale sai veskikivi, kukku, kukku, kaela peale veeretud, kukku, kukku.

H II 28, 916/7 (1) < Maarja-

Magdaleena khk - A. Vuks (1890).

Lutsi eestlastel on kolm käo tekkeversiooni.

1. Tüdrukut ahvatles kurat, kelle käest vend tütarlapse ära päästis. Nutva tütarlapse pani jumal käoks kukkuma.

2. Vend tahtis õega abielluda ning tütarlaps vastas, et pigem lendab käona metsa.

3. Ema needis ära võtme kaotanud tütre, sestsaadik kukub see käona. - Niisiis on kägu siingi saanud tütarlapsest (neiust) ja otse loomulik, et regilauludes on kägu neiu sünonüüm.

Käo pesaparasitismi on seletatud kui jumala karistust linnu pretensioonikuse või laiskuse eest. Varasemad kirjapanekud käo pesa kohta väljendavad uskumusi, et selle linnu pesa leidmine toob leidjale õnnetust või jääb ta pimedaks. Hilisemates kirjapanekutes 20. sajandist on enam taunitud käo häbematust j a laiskust ning kirjeldatud käopaari võtteid teiste lindude pesa kasutamisels: isaslind annab hüüdega "kuk-kukku" märku, et on pesa leidnud: Isakägu kukub ja mielitab veike linnu oma kallale, siis emakägu muneb kiirest oma muna veike linnu pesa [pessa] ja ise viel naerab (Iisaku).

Käopoegade toitjat nimetatakse käo sulaseks või käo naiseks. Rahvasuus on kõige sagedamini selles rollis arvatud olevat linavästrikut. Ametlik linnunimetus köosulane kuulub linnuliigile Hippolais icterina. Käo sulane või naine pole ainult ta poegade toitja. Kui kägu suvel odrapeade loomise aegu enam ei laulnud, öeldi, et käole läheb odraokas kurku ning ta muutub kulliks, keda sulane või naine ta lennul saadab. Kägu munep oma muna tõsõ pessä, kos pesäomanik näist poja vällä aud [haub]. Kui nä suurembas ommava saanu, lindava pesäst vällä. Näide audja [hauduja] lindab ütele näist järgi, et tedä tagasi kutsu. Kägu ei tulõ. Tsirk lindab timägä üten ja jääp tälle sulases. Sügise süüp kägu oma sulasõ ärä. H III 10, 249 (8) < Kambja khk, Krüüneri v. - J. Siimus (1888).

Talvel kägu ära ei rändavat, vaid murdvat väikesi linde. Lõuna-Eestis on käole omistatud isegi kanade murdmist. Setumaa usku muste järgi talvitub kägu puuõõnes, kuid välja tuleb ja kukkuma hakkab jüripäevast. 
Käo kui endelinnu kuulsus on aina seotud tema häälitsemisega. Õnnetuks linnuks või surmalinnuks on teda nimetatud mitte silmas pi dades tekkelugu, vaid et ta eluhoonete lähedusse kukkuma tulles teatab kellegi surmast. Memoraadid sellistest juhtumistest, mil kägu ilmus aeda, õunapuusse, ukselävele, aiateibasse, katusele vm. kui fataalne en delind, ringlevad tänapäevalgi.

Kui kägu tulep kodo ja kuugup, kui kuugup suu õkva õue poole, siis tulep surnu, aga kui kuugup suu mõtsa poole, siis tulep kahju: kas loom saap otsa või tulekahju, või varastadas, või murrat jalaluu. Ma talitasi sigalan, kägu tulli ja kuukus, enne olli õue, pärastpoole mõtsa poole. Ma mõtlesin, et mida... Ei olnudki palju aiga, hobene läts lõhkuma. Ma kukkusin maha, jalg jäi vankri vahele, väänas jalga, ja luu lõhki. Enne kui väimees poi hinda [poos enda], kuuk kolm korda. Ma ütli talle: "Mis sa kuugut, ma kuule küll!" - Ma mõtli, et ta minnu kuugup, aga väimees poi hinda varsti är. RKM II 346, 627/8 (12) < Rõuge khk, Põru k - K. Salve (1977).

Kägu maja juures võib olla veel raske haiguse, karilooma hukkumise, tulekahju, üldse õnnetuse, pahanduse, tüli, nälja, viljaikal duse etteteatajaks. Üksikjuhtudel on püütud halba ära hoida linnu minemaajamisega, ent tappa teda ei tohtinud. Käo tapmise (püssiga laskmise) keelu motiveeringud vihjavad tekkemuistendile või selle teo tagajärgedele: tapja hakkaks kuivama, tema parim hobune sureks. Mõnikord on silmas peetud, kuhupoole näitab linnu nokk (elamu või lauda poole), jälgitud, kuhu lendab, loendatud, mitu korda kukub (enamasti kolm korda). Karjalapsi keelati käole vastu hüüda, teda petta, narrida, osatada. Põhjendused: narrijale imeb end külge käopuuk [metspuuk]; tal kasvavad puseriti hambad; saab teises ilmas käoks; pole õnne; kägu hakkab verd sülitama.

Kevadel esmakordselt kägu kuuldes loendati, mitu korda kägu hüüab. Mõnel pool on peetud vajalikuks sõnalist pöördumist: Kuku, kuku, käokene, kullakene, nii mitu korda, kui mitu aastat ma elan või mitu aastat on pulmadeni ning seejärel asuti aastaid loendama. Kukkumise aja järgi otsustati, mida eelolev aasta toob: hommikul - hoolt, lõuna ajal - leina, õhtul - õnne. Lisandub analoogiaid: kel raha taskus, sel on kogu aasta palju raha; taskus tuleb münte kõlistada, et raha jätkuks; kui kägu kukub mere pool, saab head kalasaaki. Läänesaartel jälgiti, kas kägu kukub eesvõi tagapool, vasakul või paremal. Tähendused varieeruvad: suvel metsas karja otsides leiad need hõlpsasti (või raskustega); sinust räägitakse head (halba); ees ootab hea (või halb) õnn, ebaõnn ootab ees (või on juba seljataga). Kagu-Eestis Vene- ja Lätimaa piirialadel tuli unest lahti saamiseks kolm ringi ümber selle puu joosta, mille otsas kägu kukub, nii et lind ei märka. Teine võimalus on nii toimides tulevast ennustada selle järgi, kui kiiresti ja kuhupoole kägu ära lendab:

Puud, kus kägu kevadel kukub, piirigu [piiraku] õnneotsija üheksa korda vastupäeva ümber, plaksutagu siis käsa. Kuh upoole nüid kägu lendab, sealtpoolt saate naese ehk lähete sen napoole mehele. Ei lenda aga kägu kohe ära, peate veel kaua abieluõnne ootama. E 1178 (30) < Põlva khk, Navi k. - J. Melzov (?).

Käost kardeti rohkem kui ühestki teisest linnust, et ta inimese ära petab, kui see linnupetet võtmata, s.o. söömata välja läheb ja kevadel esimest korda kägu kuuleb. Petetule tähendas see kuivamist, kõhnumist, haigust, jõuetust, kurtumist, surma. Mainitud on veel laisaksjäämist, unisust eeloleval 
aastal, mahajäämist töös, tuleõnnetust, peavalu, söögiisu kadumist, suu haisemist (Võrumaa), metspuukide külgetulekut (Vaivara), enda põletamist, täide saamist, adra raudpuu või künnipuu kat kiminekut, eksimist (ka moraalireeglite vastu), pettasaamist (ka armuasjades). Petetu ei tohtinud sügisel pärast viimast karjapäeva loomi laudas kinni või kütkesse panna, et kari ei kurtuks. Petmise halb mõju tuli kas vavale puule üle kanda kolm (ka: 7, 9) korda ümber puu kõndides ja seda närides, et inimese asemel kuivaks puu. Üksikjuhtudel on nimetatud puuliik: lepp, pihlakas, kask, kadakas, õunapuu. Leidub kirjeldusi, et nii toimiti ja puu kuivaski tegelikult.

Kui kukulind kevade ära situb, siis jääb see sui aigeks. Kui kukulindu kuuled ja põle söönd mette, siis ammusta toore puu sisse, siis sulle ei mõju, aga puu lehed kuivavad ära. Mo ema oli am mustand pihla sisse, ei lehed põle tal suuremaks kasvand kui kevade olid. Teise aasta akand jälle uuesti kasvama. ERA II 189, 271 (35) < Pühalepa khk ja v, Palade k - E. Ennist (1938)

Käo saabumine vara (3, 5, 9 päeva enne jüripäeva) on külma kevade enne. Jälgitud on käo saabumise ja teiste fenoloo giliste orientiiride samaaegsust. Kui mets oli raagus, arvati tulevat hea vilja-aasta, kui lehes, siis leiva-, leina või ka nälja-aasta. On ka muid sõnaalguse häälikuanaloogiast lähtuvaid, mõneti juhuslikke seletusi. Soodus viljakülvi (oder, hernes) aeg on siis, kui käod võidu kuku vad. Käo "kogelemine" on enamasti vihmaenne. Käolaulu lõppu suvel on arvestatud jaanipäeva, peetripäeva (29. juuni) ning heinamaarjapäeva (2. juuli) järgi. Kui kägu kaua pärast neid tärmineid kukub, tuleb soe ja pikk sügis, külm ei võta vilja.

künnivares Corvus frugile gus. Seletusmuistendi järgi saavad mustadeks varesteks või *hakkideks need ronga pojad, keda vana ronk suurel reedel enne päikesetõusu ristida ei jõua. Ronk pidavat oma pojad enne päeva Emajões ära ristima, muidu jäävad musteks varesteks. Nüüdisaja rongad seda kommet vist ei tea, ega muidu neid muste varesid nii palju ei oleks ja ronke ei kuule-näe ühtegi enam. ERA II 121, 131 (15) < Karksi khk - M. Sarv (19351936).

Lutsi eestlastelt pärit versiooonis määras jumal mustaksmäärdunud varese alatiseks musta kuube kandma.
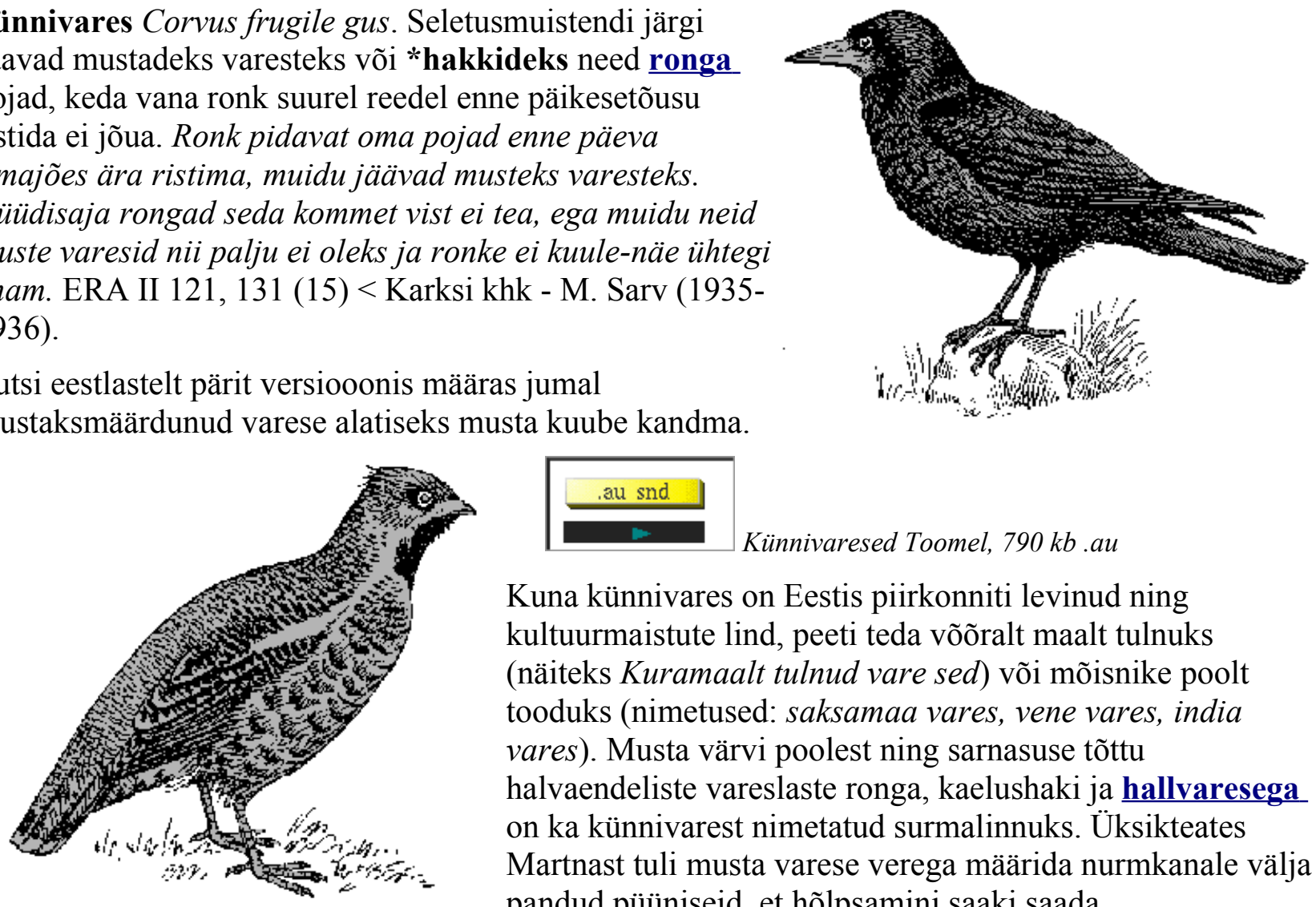

Kuna künnivares on Eestis piirkonniti levinud ning kultuurmaistute lind, peeti teda võõralt maalt tulnuks (näiteks Kuramaalt tulnud vare sed) või mõisnike poolt tooduks (nimetused: saksamaa vares, vene vares, india vares). Musta värvi poolest ning sarnasuse tõttu halvaendeliste vareslaste ronga, kaelushaki ja hallvaresega on ka künnivarest nimetatud surmalinnuks. Üksikteates Martnast tuli musta varese verega määrida nurmkanale välja pandud püüniseid, et hõlpsamini saaki saada. 
laanepüü Tetrastes bonasia. Jahimeeste uskumuse järgi saab laanepü̈d lasta tingimusel, et jahimees näeb lindu enne, kui lind teda näeb. Siis jääb lind paigale. Kui laanepüü jahimeest esimesena näeb, siis lendab lind kohe ära, püss ei taba.

lapi kull - vt nõiakull

metsvint - vt lepalind

must vares - vt künnivares

lepalind. Lepalinnuks on nimetatud metsvinti, ka aedlepalindu, punarinda jt. punaka sulestikuga värvulisi. Nii linnunimetus lepalind kui punaka puiduga puuliik lepp lähtuvad ühisest läänemeresoome sõnatüvest, mis tähendab verd. Legendis on punane värvus saadud heateo eest Kristuse ristil.

Miks lepalinnul kurgualune punane.

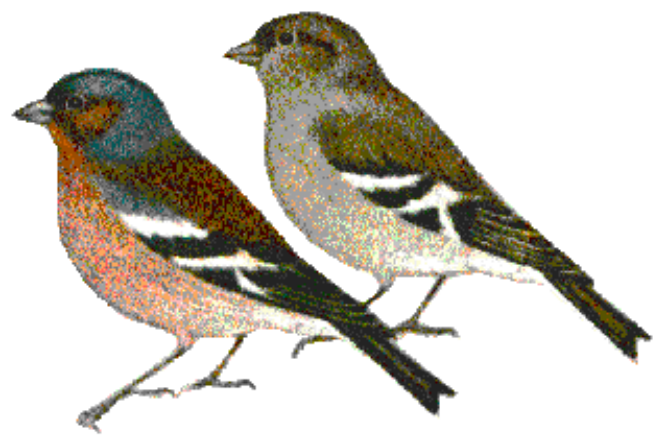

Kui Jeesus risti peal rippus, siis üks väike hall lind tahtis teda sealt päästa. Ta katsunud naelu välla koukida, siis veri tilkunud talle kurgu alla ja ta kurgualune jäi sestsaadiks punaseks. Teda hüütakse lepalind. ERA II, 626 (49) < Rapla khk Kabala v Pühatu k - E. Poom (1938).

Usuti, et lehm hakkab verd lüpsma (kusema), kui lepalind tema kõhu alt läbi lendab. Sama on arvatud *pääsukese lendamisest. Hiiumaa uskumus on, et lehm haigestub "punasesse", kui lepalinnu pesa peale astub või kui karjalapsed selle linnu pesa lõhuvad. Haige looma raviks on oluline lepapuud kasutada: haigest udarast piima lüpsta kolme maassepistetud lepatiku peale; kolm lepakoore tükki ternespiima keetmise ajal piima sisse poetada; lehma uriiniloigu ümber oksi pista ning raudkivi keskele asetada.

\section{Kirjandus}

AT - Aarne, A.; Thompson, St. 1961: The Types of the Folktale, FFC nr. 184. Helsinki.

Hiiemäe, M. 1982. Ei tohi peale hingata. Uskumusi linnupesadest. Eesti Loodus, 6, 1k. 390-395.

Hiiemäe, M. 1983. Vares vaagub vihma. Eesti Loodus, 5, 1k. 313-314.

Hiiemäe, M. 1985. Linnud ilmaennetes. Eesti Loodus, 12, 1k. 792-797.

Loorits, O. 1949. Grundzüge des estnischen Volksglauben I. Lund, 1k. 355-359.

Loorits, O. 1954. Neue Beiträge zum Vogelbetrug-Motiv. Suomalais-ugrilaisen Seuran Aikakauskirja 57, 1k. 1-19.

Mäger, M. 1967. Eesti linnunimetused. Tallinn.

Mäger, M. 1969. Linnud rahva keeles ja meeles. Tallinn.

Oinas, F. J. 1984. Linnupete. Vargamäe tõde ja õigus. Esseid. Truth and Justice of Vargamäe and 
other Essays. (res. Cheating by the Bird, 1k. 257), Välis-Eesti \& EMP, 1k. 149-161.

Salve, K. 1992. Lorijal lõuvad, kuuljad kõrvad (Ida-Virumaa rahvajuttud est). Ida-Virumaa rahvakultuurist. Tallinn, $1 \mathrm{k} .82-100$.

Zelenin, D. 1938. Der alte estnische Brauch. den Vogelbetrug essen (linnupetet sööma). Litterarum societas Esthonica 1838-1938. Liber Saecu laris II. Tartu, 1k. 865-879.

\section{Joonised ja pilditahvlid}

Kumari, E. 1974 Eesti lindude välimääraja. Tallinn.

Kumari, E. 1984 Eesti lindude välimääraja. Tallinn.

\section{Helinäited}

Helinäited pärinevad Eesti Raadio arhiivist. Kasutatud on Fred Jüssi ja B. Veprintsevi salvestusi, plaate "British Bird Songs and Calls", kassette "Maaseutulinnut", "Lapin kevät ja kesä", "Laulava lintukirja". Täname abi eest Toomas Jüriadot. 